\title{
Identification of salt-induced genes from Salicornia brachiata, an extreme halophyte through expressed sequence tags analysis
}

\author{
Bhavanath Jha ${ }^{1 *}$, Pradeep K. Agarwal ${ }^{1}$, Palakolanu Sudhakar Reddy ${ }^{2}$, Sanjay Lal ${ }^{1}$, \\ Sudhir K. Sopory ${ }^{2}$ and Malireddy K. Reddy ${ }^{2}$ \\ ${ }^{1}$ Discipline of Marine Biotechnology and Ecology, Central Salt and Marine Chemicals \\ Research Institute (Council of Scientific and Industrial Research), \\ Bhavnagar-364 002, Gujarat, India \\ ${ }^{2}$ Plant Molecular Biology Group, International Centre for Genetic Engineering \\ and Biotechnology, Aruna Asaf Ali Road, \\ New Delhi 110 067, India
}

(Received 22 December 2008, accepted 1 April 2009)

Salinity severely affects plant growth and development causing crop loss worldwide. We have isolated a large number of salt-induced genes as well as unknown and hypothetical genes from Salicornia brachiata Roxb. (Amaranthaceae). This is the first description of identification of genes in response to salinity stress in this extreme halophyte plant. Salicornia accumulates salt in its pith and survives even at $2 \mathrm{M} \mathrm{NaCl}$ under field conditions. For isolating salt responsive genes, cDNA subtractive hybridization was performed between control and $500 \mathrm{mM} \mathrm{NaCl}$ treated plants. Out of the 1200 recombinant clones, 930 sequences were submitted to the NCBI database (GenBank accession: EB484528 to EB485289 and EC906125 to EC906292). 789 ESTs showed matching with different genes in NCBI database. 4.8\% ESTs belonged to stress-tolerant gene category and approximately $29 \%$ ESTs showed no homology with known functional gene sequences, thus classified as unknown or hypothetical. The detection of a large number of ESTs with unknown putative function in this species makes it an interesting contribution. The 90 unknown and hypothetical genes were selected to study their differential regulation by reverse Northern analysis for identifying their role in salinity tolerance. Interestingly, both up and down regulation at $500 \mathrm{mM} \mathrm{NaCl}$ were observed ( 21 and 10 genes, respectively). Northern analysis of two important salt tolerant genes, ASR1 (Abscisic acid stress ripening gene) and plasma membrane $H^{+} A T P a s e$, showed the basal level of transcripts in control condition and an increase with $\mathrm{NaCl}$ treatment. ASR1 gene is made full length using 5' RACE and its potential role in imparting salt tolerance is being studied.

Key words: ESTs, Salicornia brachiata, salt tolerance, subtractive hybridization

\section{INTRODUCTION}

Abiotic stress is the primary cause of crop loss world wide, reducing average yields of major crop plants by more than 50\% (Bray et al., 2000; Vinocur and Altman, 2005). The problem is huge, almost 1000 million ha of land is affected by soil salinity (Szabolcs, 1994), 7\% of total land area. Of the 1.5 billion ha cultivated land, about 5\% (77 million ha) is affected by salt (Munns et al., 1999). Plants growing in a particular habitat are often

Edited by Yoshibumi Komeda

* Corresponding author. E-mail: bjha@csmcri.org well adapted to the environmental stress conditions at that place. Understanding of the molecular processes regulating these metabolic adaptations will facilitate engineering of abiotic stress tolerance. The molecular mechanism of salt adaptation in halophytes is far improved compared to glycophytes. Salicornia brachiata is a highly salt tolerant plant than most other genera of halophytes. It is a leafless annual small bushy plant that grows up to $50 \mathrm{~cm}$ in height and has tiny flowers within green jointed succulent stem that forms seedbearing spikes. S. brachiata can grow in wide range of salt concentrations, accumulating $40-50 \%$ salt of its dry weight. The vegetable salt from Salicornia is known as 
Saloni, contains $5-7 \% \mathrm{KCl}$ along with $\mathrm{NaCl}$, making it suitable for the high blood pressure patient. Calcium, magnesium and iodine micronutrients are naturally present in the Salicornia salt (Ghosh et al., 2005; US patent no. 6929809).

Expressed sequence tags (ESTs) analysis is an effective method, for getting information of gene expression and also provides an opportunity to identify new genes involved in biological functions. Various researchers have recently reported genes and ESTs, induced by cold, drought, high salinity stress and ABA in many plant species (Amtmann et al., 2005; Vinocur and Altman, 2005; $\mathrm{Xu}$ et al., 2007). There are few reports on ESTs generation and analysis in response to salt treatment on different halophytes like Suaeda salsa (Zhang et al., 2001), Tamarix androssowii (Wang et al., 2006), Thellungiella halophila (Wang et al., 2004), Mesembryanthemum crystallinum (Kore-eda et al., 2004) and Avicennia marina (Mehta et al., 2005).

The present study reports identification of genes in response to salinity in the extreme halophyte plant $S$. brachiata. The ESTs are analyzed and classified according to their putative functions. The expression of 90 unknown and hypothetical genes was studied by reverse Northern analysis. Transcript analysis of ASR1, PM$H^{+}$ATPase revealed its expression with salt stress.

\section{MATERIALS AND METHODS}

Isolation of ESTs Salicornia seeds were germinated in plastic pots containing garden soil. One set of twomonth-old seedlings was exposed to $500 \mathrm{mM} \mathrm{NaCl}$ stress treatment for $24 \mathrm{~h}$ whereas a duplicate set of seedlings were maintained under control conditions. Total RNA was isolated from shoot material using Guanidiumisothiocyanate method. The cDNA from both control and $\mathrm{NaCl}$ treated plants were prepared using manufacture's protocol (Invitrogen, USA). Subtractive hybridization was carried out to normalize the sequence abundance and to enrich the differentially expressed clones involved in salinity stress according to the Mishra et al. (2005). The 5 ' end of each cDNA was ligated with an adaptor containing EcoRI site. cDNA was ligated unidirectionally into EcoRI and XhoI site of the phage lambda Zap expression vector according to the manufacturer's instruction using a Uni-Zap-XR cDNA library construction kit (Stratagene, LaJolla, California, USA). Individual recombinant plaques from the primary cDNA library were manually transferred into 96 well format flat bottom storage plates containing $200 \mu \mathrm{l} \mathrm{SM}$ buffer $(100 \mathrm{mM} \mathrm{NaCl}, 8 \mathrm{mM}$ $\mathrm{MgSO}_{4} .7 \mathrm{H}_{2} \mathrm{O}, 50 \mathrm{mM}$ Tris- $\mathrm{HCl} \mathrm{pH} 7.0,0.04 \%$ gelatin) supplemented with $5 \%$ DMSO and $0.5 \%$ chloroform. The cDNA inserts from each recombinant phage were PCR amplified, with $150 \mathrm{ng}$ of universal M13 forward and reverse primers (5'-GTAAAACGACGGCCAGT-3' and 5'-
CAGGAAACAGCTATGAC-3'), using $1 \mu \mathrm{l}$ of recombinant phage suspension as a template in $100 \mu \mathrm{l}$ reaction volume for 30 cycles with the following PCR conditions, $94^{\circ} \mathrm{C}$ for $1 \mathrm{~min}, 55^{\circ} \mathrm{C}$ for $1 \mathrm{~min}$ and $72^{\circ} \mathrm{C}$ for $2 \mathrm{~min}$. PCR amplified cDNA inserts were purified using Strataprep 96 PCR purification kit (Stratagene) to remove unincorporated primers and nucleotides. The size and quality of cDNA inserts were monitored on agarose gels. All the PCR amplified products having a $200 \mathrm{bp}$ or larger cDNA inserts were re-arrayed into a new 96-well PCR plate. One micro litre of purified PCR amplified cDNA inserts were directly used as template for cycle sequencing using DYEnamic ${ }^{\mathrm{TM}}$ ET terminator cycle sequencing kit (Amersham Biosciences) with T3 sequencing primers according to the manufacturers instructions and sequencing was performed on mega base sequencer. The raw sequencing data was processed to remove the poor quality sequences using PhredPhrap (Ewing and Green, 1998) software and vector and adaptor sequences by cross_match software. BLASTX 2.2.19+ programme of NCBI (Altschul et al., 1997) is used for searching sequence similarity between processed cDNA sequence outputs and non-redundant amino acid public database. The BLASTX hit lower than $\mathrm{E}$ value $=1 \mathrm{e}-2$ was considered for the functional annotation of the ESTs sequence.

Northern analysis To study the expression of ASR1 (EB484610) and PM-H ATPase (EB484660) gene, twomonth old seedlings were treated with different concentration of $\mathrm{NaCl}$ ranging from $0.01 \mathrm{M}$ to $2 \mathrm{M}$ for $24 \mathrm{~h}$. In another experiment the plants were treated with $0.250 \mathrm{M}$ $\mathrm{NaCl}$ for different time periods like 2, 4, 8, 12, 18, 24, 36, 48 and $72 \mathrm{~h}$ to study the time course transcript expression. Total RNA was isolated from the treated plants (shoot) using Guanidium - isothiocyanate method. Approximately $20 \mu \mathrm{g}$ of total RNA was resolved on $1 \%$ formaldehyde agarose gel and transferred to positively charged Hybond $\mathrm{N}$ membrane. The blots were probed with $\left[\alpha^{32} \mathrm{P}\right]$-labelled (nick translated) partial length of ASR 1 and PM-H $H^{+}$ATPase ESTs. Hybridization and post hybridization washes were carried out as reported earlier (Reddy et al., 1998). The blots were autoradiographed. The signal intensity of RNA bands was quantified using Gene analysis tool software (Cambridge, U.K.), and plotted as relative value with respect to ribosomal RNA band as control for each treatment separately.

Reverse Northern Analysis The selected ninety clones were PCR amplified $\left(94^{\circ} \mathrm{C}\right.$ for $1 \mathrm{~min}, 55^{\circ} \mathrm{C}$ for $1 \mathrm{~min}$ and $72^{\circ} \mathrm{C}$ for $2 \mathrm{~min}$ ) using $1 \mu \mathrm{l}$ phage stock of the hypothetical and unknown genes obtained during the subtractive hybridization. The concentration of the amplified product was determined using the Nanodrop spectrophotometer (ND1000, USA). Equal volume $(2 \mu \mathrm{g})$ of each 
amplified product was electrophoresed on two different $1 \%$ agarose gels $(0.5 \mathrm{x}$ TBE) simultaneously. The DNA from both the gels were transferred to positively charged Hybond $\mathrm{N}$ membrane and immobilized by UV crosslinking (U.V. 500 Crosslinker, Amersham Bioscience, USA). Total RNA was isolated from control and $500 \mathrm{mM} \mathrm{NaCl}$ treated $(24 \mathrm{~h})$ plants using Guanidium-isothiocyanate method. mRNA was isolated using PolyATract ${ }^{\circledR}$ mRNA Isolation Systems (Promega, USA). Two microgram of each mRNA from both control and salt treated plants were used for cDNA synthesis in the presence of $\left[\alpha^{32} \mathrm{P}\right]$ dCTP. One set of blots were hybridized with control cDNA probe and other with salt treated cDNA probe. Hybridization and post hybridization were carried out as mentioned earlier (Reddy et al., 1998). The blots were autoradiographed and the bands were compared to analyze up-regulated and down- regulated genes.

\section{RESULTS AND DISCUSSION}

Single pass sequence of random cDNA A total of 1200 clones were picked up and analyzed by the PCR. The PCR reaction with M13 forward and reverse primers confirmed 1002 clones to be recombinant. Poor quality sequences and the 5 ' adaptor sequences if found were removed. Out of the 1002 sequences, 930 sequences were submitted to the NCBI database (GenBank accession number EB484528 to EB485289 and EC906125 to EC906292) while the remaining poor quality sequences, were discarded.

Putative identification of EST sequences Out of 930 sequences 789 ESTs showed similarity with known or unknown category of genes in NCBI database. These
ESTs were grouped into 13 functional categories including defense and cell rescue $(4.8 \%)$, protein metabolism and sorting (3.0\%), membrane transporters $(3.8 \%)$, gene expression and RNA metabolism (11.2\%), photosynthesis (10.9\%), signaling component (4.3\%), metabolism enzymes (14.8\%), cell wall structure (2.5\%), cell division, cycle and growth $(3.8 \%)$, cytoskeleton $(0.9 \%)$, energy $(1.14 \%)$, miscellaneous (8.9\%) and unknown or hypothetical (29.8\%) (Fig. 1). Some of the genes in high abundance like ribosomal protein, Rubisco small subunit, metallothionein, $\mathrm{Chl} \mathrm{a} / \mathrm{b}$ binding are given in Table 1. Approximately $29 \%$ of ESTs did not exhibit homology with known genes, thus were classified in unknown category. In total population, $4.8 \%$ sequences showed similarity with salt stress related genes. The stress related genes are grouped into six different classes on the basis of their major function like general stress proteins, signaling components, reactive oxygen species scavengers, transmembrane transporters and ion homeostasis and transcriptional regulators (Table 2).

In our study, after $4 \mathrm{~h}$ of $\mathrm{NaCl}$ treatment, plants started to show signs of wilting but got resurrected after $24 \mathrm{~h}$. The resurrection shows that the normal metabolism gets resumed in halophytic environment reflecting the unique property of halotolerant plants. The representation of high number of ribosomal proteins, Rubisco small subunit and $\mathrm{Chl} \mathrm{a} / \mathrm{b}$ binding genes indicate that plants remained healthy even in the presence of $\mathrm{NaCl}$. Similarly a high number of these genes were also procured in ESTs analysis of other halotolerant plants like Suaeda salsa (Zhang et al., 2001), Tamarix androssowii (Wang et al., 2006), Thellungiella halophila (Wang et al., 2004) and Mesembryanthemum crystallinum (Kore-eda et al., 2004).

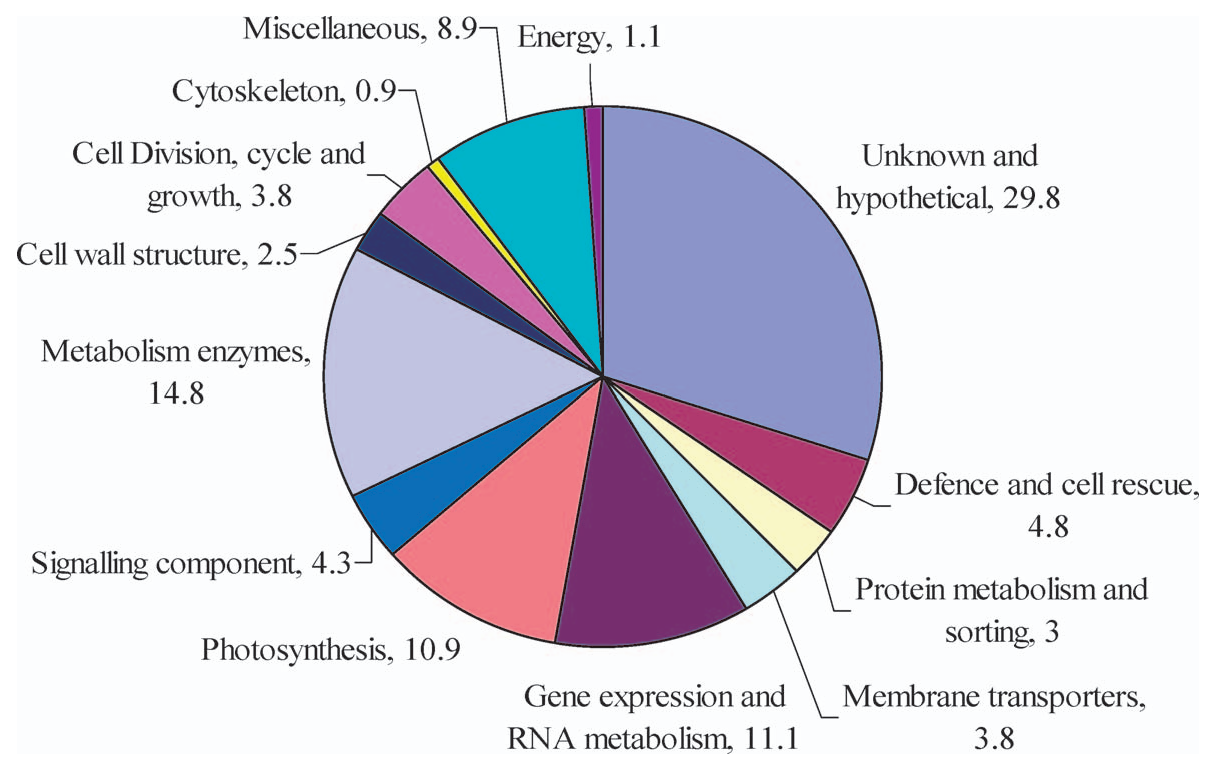

Fig. 1. Functional classification of ESTs of S. brachiata, values against each classification are given in percentage. 
Table 1. Most abundant mRNA

\begin{tabular}{lcc}
\hline \hline Putative identification & No. of ESTs & Percentage of total ESTs \\
\hline Ribosomal Protein & 27 & 3.33 \\
Rubisco small subunit & 17 & 2.09 \\
Metallotheionin & 15 & 1.85 \\
Chl a/b binding & 23 & 2.83 \\
Unknown/unnamed & 75 & 9.25 \\
Hypothetical & 165 & 20.37 \\
\hline
\end{tabular}

Table 2. Abundance profile of genes related to salt tolerance

\begin{tabular}{lcc}
\hline \hline Putative identification & No. of ESTs & $\begin{array}{c}\text { Percentage of } \\
\text { total ESTs } \\
(789)\end{array}$ \\
\hline Stress protein & 5 & 0.63 \\
Signaling component & 9 & 1.140 \\
Reactive oxygen species & 16 & 2.02 \\
Transmembrane transporters & 3 & 0.38 \\
and Ion homeostasis & & \\
Transcriptional regulators & 5 & 0.63 \\
TOTAL & 38 & 4.81 \\
\hline
\end{tabular}

Functional classification of salt related ESTs

Whether halophytes have a distinct signaling pathway and regulatory network to impart the salt stress tolerance is not clear. Environmental signals are first perceived by specific receptors, which modulate expression and activation of different genes leading to stress tolerance. Many salt related genes involved in abiotic stress signaling pathways are found in S. brachiata ESTs (Table 3). Calmodulin, $\mathrm{Ca}^{2+}$ binding proteins and receptor like serine threonine kinase known in the literature as signaling components involved in various signal cascades, are present in the Salicornia ESTs. Serine threonine kinase is an important signaling molecule that transmits the signal to down stream transcriptional regulators and other stress related genes. Similarly, calmodulin and serine threonine kinase are also reported in Thellungiella halophila from salt treated seedlings (Zhang et al., 2008).

Presence of $\mathrm{NaCl}$ imposes both ionic and osmotic stress on plants. Salt stress causes physiological drought to the plants and activates the drought responsive genes. The damage due to salt stress in plants is not only because of toxicity of $\mathrm{Na}^{+}$ions but also a response to hyper osmotic stress. We found the drought resistance genes like Abscisic acid and stress induced protein, early response to dehydration (erd) proteins in Salicornia ESTs. This gene shows expression in drought condition in Arabidopsis (Kiyosue et al., 1994).

Ion transporters help in achieving greater tolerance by maintaining cytosolic ion homeostasis. Ions transporters selectively transport ions and maintain them at physiologically relevant concentration. Genes related to ion transporters like $\mathrm{ABC}$ transporters are reported in the present ESTs. Secondary active transport and electrochemical flux across the plasma membrane and tonoplast are driven by $\mathrm{H}^{+}$pump and VATPase. Salicornia ESTs represents the plasma membrane associated $\mathrm{H}^{+}$ATPase and VATPaseC encoding genes, however, tonoplast $\mathrm{H}^{+}$-PPase was not present. Similary in Suaeda (Zhang et al., 2001), Thellungiella (Wang et al., 2004) the V-type ATPaseC subunits were also reported. The Salicornia PM-H ${ }^{+}$ATPase showed $75 \%$ identity with $M$. crystallinum. In Tamarix both plasma membrane $H^{+}$ATPase and VATPaseC ESTs were present. In $S$. salsa $\mathrm{Na}^{+}$accumulated seedlings showed increased VATPase activities induced by salt treatment and no clear pattern was detected for NaCl-dependent P-ATPase and V-PPase activity changes. Thus, P-ATPase and V-PPase seem to be less important physiologically than V-ATPase in S. salsa under salt stress (Wang et al., 2008). Salicornia plant similar to Suaeda accumulates salt in its succulent tissue. Previous studies with Salicornia demonstrated the accumulation of $\mathrm{NaCl}$ in pith region (Reddy et al., 1993), reflecting that the intercellular space provides more room for accumulating $\mathrm{NaCl}$ and reducing the toxicity in cytoplasm. In case of Salicornia, cell to cell transport and membrane transport seem to be a major phenomenon and that may be a possible reason for absence of $\mathrm{H}^{+}$-PPase from the EST in the present study. However, in future we will try to clone this gene using degenerate primers to ascertain its function in ion homeostasis.

The abiotic stresses lead to the production of ROS such as $\mathrm{O}_{2}, \mathrm{H}_{2} \mathrm{O}_{2}$ and $\mathrm{OH}^{-}$(Price et al., 1989; Moran et al., 1994; Mittler, 2002), which damage membranes and macromolecules. ROS scavenging is an important aspect to combat abiotic stress. Plants produce different antioxidant enzymes such as catalase (CAT), sodium dismutase (SOD), ascorbate peroxidase (APX), glutathione S-transferase (GST) and glutathione reductase (GSR). Salicornia stress induced ESTs also showed different genes related to ROS scavenging. The peroxisomal isoform of ascorbate peroxidase (APX) is a novel membrane isoform that functions in the regeneration of $\mathrm{NAD}^{+}$and protection against toxic reactive oxygen species (Shigeoka et al., 2002). The intracellular localization and sorting of peroxisomal-APX has been reported and it has been shown to be involved in antioxidant defenses in different cellular compartments during development and abiotic stress (Teixeira et al., 2006). In our ESTs the peroxisomal ascorbate peroxidase is present. $p A P X$ gene was also observed in Thellungiella (Wang et al., 2004) and Suaeda (Zhang et al., 2001). This gene showed high homology with Hordeum vulgare (Shi et al., 2001). We found the thioredoxin $\mathrm{M}$ and $\mathrm{H} 3$ type in our database, which have earlier been shown to be associated with 
Table 3. Genes related to stress tolerance

\begin{tabular}{|c|c|c|c|c|c|}
\hline Class of target & Functional annotation & Matching with & $\begin{array}{l}\text { EST } \\
\text { clones } \\
(\mathrm{n})\end{array}$ & $\mathrm{E}$ value & $\begin{array}{l}\text { Gene bank } \\
\text { Accession } \\
\text { No. }\end{array}$ \\
\hline \multirow[t]{5}{*}{ Stress protein } & Putative ripening protein & Ipomea nil & 1 & $3 e-15$ & EB484610 \\
\hline & Salt-induced hydrophilic protein & A. nummularia & 1 & $7 e-03$ & EB484820 \\
\hline & Jasmonate-induced protein & Atriplex canescenes & 1 & $3 e-02$ & EB484860 \\
\hline & Cold-regulated protein & H. vulgare & 1 & $3 e-36$ & EB485107 \\
\hline & Early response to dehydration & A. thaliana & 1 & $2 \mathrm{e}-04$ & EB484814 \\
\hline \multirow[t]{9}{*}{ Signaling component } & NADH-ubiquinone oxidoreductase & Z.mays & 1 & $1 e-40$ & EB484739 \\
\hline & Poly-ubiquitin & A. lyrata & 2 & $4 e-101$ & EB484798 \\
\hline & Calmodulin & B. vulgeris & 1 & $4 e-12$ & EB484584 \\
\hline & Putative calcium-binding protein & G. hirsutum & 1 & $2 \mathrm{e}-30$ & EB484655 \\
\hline & Ubiquitin conjugating enzyme & A. thaliana & 1 & $2 e-69$ & EB484561 \\
\hline & Protein kinase family protein & A. thaliana & 1 & $1 e-64$ & EB484781 \\
\hline & Protein phosphatase $2 \mathrm{C}$ & A. thaliana & 1 & $3 e-46$ & EC906270 \\
\hline & Serine threnine protein kinase & Populus tremula & 1 & $8 \mathrm{e}-02$ & EB484994 \\
\hline & Phospholipase C & Spinacea olercea & 1 & $1 e-87$ & EC906136 \\
\hline \multirow{16}{*}{$\begin{array}{l}\text { Reactive oxygen } \\
\text { scavangers }\end{array}$} & Thioredoxin M type & Spinacea olercea & 1 & $2 e-69$ & EB484747 \\
\hline & Thioredoxin H3 type & I. batatas & 1 & $4 \mathrm{e}-19$ & EC906240 \\
\hline & Peroxisomal ascorbate peroxidase & H. vulgare & 1 & $3 e-52$ & EB484785 \\
\hline & Peroxidase & Spinacea olearcea & 1 & $8 e-59$ & EC906126 \\
\hline & Qquinone-reductase 1 & A. thaliana & 1 & $1 e-33$ & EC906139 \\
\hline & Carbonic anhydrase & Stiga asiatica & 1 & $6 e-19$ & EB484614 \\
\hline & Glutathione S-transferase 1 & Dianthus caryophyllus & 1 & $7 \mathrm{e}-72$ & EC906146 \\
\hline & CP12 & Spinacea oleracea & 1 & $2 \mathrm{e}-23$ & EC906169 \\
\hline & Short-chain dehydrogenase & S. tuberosum & 1 & $3 e-37$ & EB484813 \\
\hline & Putative serine-glyoxylate aminotransferase & Fritillaria agrestis & 1 & $3 e-33$ & EC906212 \\
\hline & Glyceraldehyde-3-phosphate dehydrogenase & Oryza sativa & 1 & $6 e-85$ & EB484991 \\
\hline & Hydroxypyruvate reductase & Brugiera gymnorrhiza & 1 & $6 e-49$ & EC906242 \\
\hline & NADH:ubiquinone oxidoreductase & Clamydomonas & 1 & $3 e-25$ & EB484739 \\
\hline & Cinnamoyl-CoA reductase & Capsicum annum & 1 & $1 e-32$ & EB484761 \\
\hline & Benzoquinone reductase & Gossypium hirsutum & 1 & $8 e-74$ & EB484772 \\
\hline & Putative hydrolase & Glycine $\max$ & 1 & $5 e-04$ & EB485139 \\
\hline \multirow{3}{*}{$\begin{array}{l}\text { Transmembrane } \\
\text { transport and ion } \\
\text { homeostasis }\end{array}$} & $\mathrm{ABC}$ transporter family protein & A. thaliana & 1 & $1 e-06$ & EB485217 \\
\hline & plasma membrane $\mathrm{H}^{+}$ATPase & M. truncatula & 1 & $8 e-44$ & EB484660 \\
\hline & VATPaseC & A. thaliana & 1 & $1 \mathrm{e}-34$ & EB484898 \\
\hline \multirow{5}{*}{$\begin{array}{l}\text { Transcriptional } \\
\text { regulators }\end{array}$} & HD-Zip & C. annum & 1 & $3 e-20$ & EB484697 \\
\hline & Putative nucleic acid binding protein & A. thaiana & 1 & $7 \mathrm{e}-20$ & EB484600 \\
\hline & WRKY 27 & T. aestivum & 1 & $3 e-08$ & EB484569 \\
\hline & Transcription factor Ntlim 1 & Nicotiana tabacum & 1 & $2 \mathrm{e}-06$ & EC906216 \\
\hline & $\begin{array}{l}\text { Protein transporter enzyme } \\
\text { transporter activity }\end{array}$ & A. thaliana & 1 & $4 \mathrm{e}-10$ & EB485129 \\
\hline
\end{tabular}


tolerance to oxidative stress. Different homologs of thioredoxin were expressed in yeast to correlate their function and it was found that TRX $m$ and TRX $x$, but not TRX $f$, affected the tolerance to oxidative stress induced by either hydrogen peroxide or an alkyl hydroperoxide (Issakidis-Bourguet et al., 2001). We have also found GST gene in Salicornia ESTs. GST is also reported in EST database of different halophytes, Aeluropus littoralis (Zouari et al., 2007), Thellungiella (Wong et al., 2005). The GST gene is made full length and the sequence has been submitted in the NCBI GenBank (Accession number EF373062) and further being analyzed for its potential role in salt tolerance.

Stress tolerance in plants is a multigenic trait and involves multiple genes and pathways to impart tolerance against the stress (Vinocur and Altman, 2005). Transcription factors are quite important to study the stress tolerance behavior in vivo since these can activate a whole array of genes involved in stress, therefore, can impart tolerance in a more effective way as compare to a single functional gene. The transcription factors are present in large number in the plants. Arabidopsis genome encodes approximately $5.9 \%$ transcription factors (Riechmann et al., 2000). In different halophytes transcription factors form an important component of EST database as evident in Aeluropus littoralis (Zouari et al., 2007), Mesembryanthemum (Kore-eda et al., 2004), Suaeda (Zhang et al., 2001), Thellungiella (Wong et al., 2005). In Thellungiella, Wong et al. (2005) have reported that $1 \%$ genes belong to transcription or signal transduction elements. In Salicornia ESTs, some important transcription factors are present, like Zn finger, DNA binding protein etc. Zinc finger protein 1 (ThZF1) from Thellungiella showed involvement in drought and salt stress (Xu et al., 2007).

Northern analysis of $A S R 1$ and $P M-H^{+} A T P a s e$ from ESTs data base Abscisic acid stress ripening gene

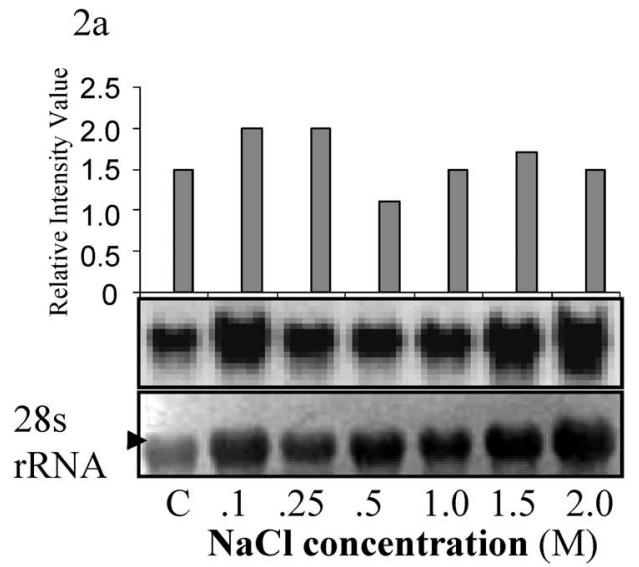

$3 \mathrm{a}$

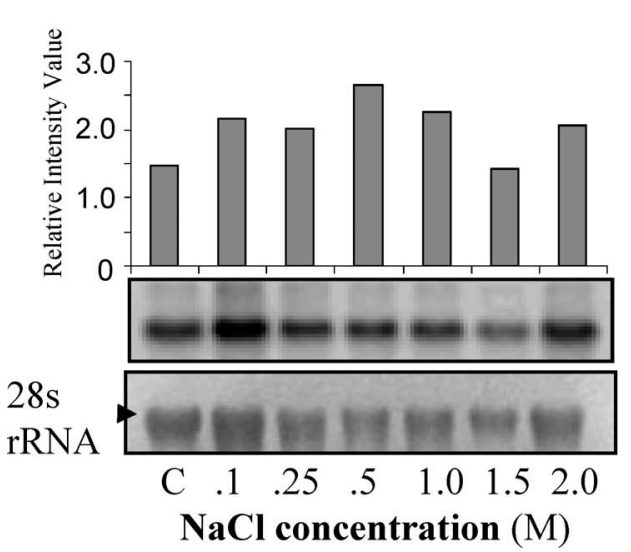

$2 \mathrm{~b}$

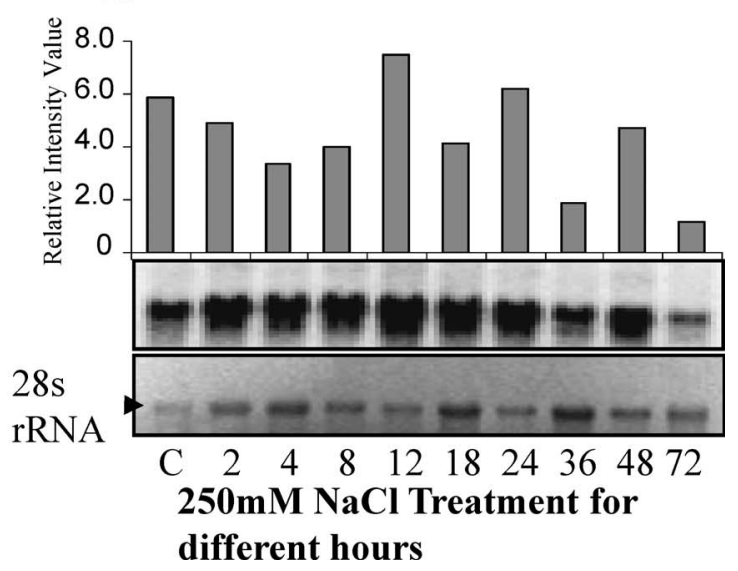

$3 b$

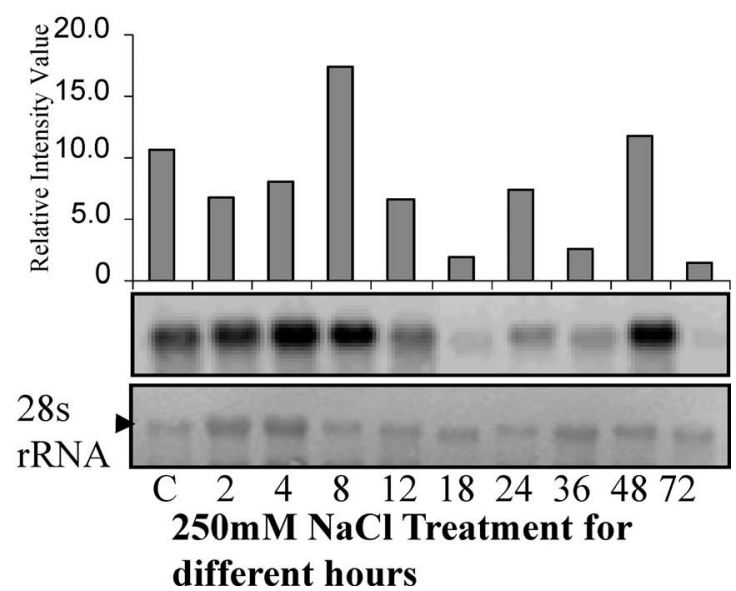

Figs. 2 and 3. Figures show the Northern analysis of $A S R 1$ gene and $P M-H^{+} A T P a s e$ gene under different salt concentration ( $2 \mathrm{a}$ and $3 \mathrm{a}$ ) and at $250 \mathrm{mM} \mathrm{NaCl}$ for different time period ( $2 \mathrm{~b}$ and $3 \mathrm{~b}$ ). Approximately $20 \mu \mathrm{g}$ of total RNA was loaded onto each well. Graphic representation over each radiograph shows the relative value of transcript against the 18S rRNA to show the quantitative increase in the expression levels. 
(ASR1) was first cloned from tomato encoding a highly charged 13-kDa protein (Iusem et al., 1993) and thereafter isolated from several plant species of dicotyledonous and monocotyledonous plants (Maskin et al., 2001; Carrari et al., 2004). Being developmentally regulated during fruit ripening this gene has also shown the expression in both salt and drought. Over-expression of tomato ASR1 and an ortholog LLA23 from Lilium longiflorum in tobacco (Kalifa et al., 2004) and Arabidopsis (Yang et al., 2005), respectively, showed increased tolerance to salt and drought. We have also isolated full length ASR1 gene from Salicornia. This gene shows $74 \%$ identity with $M$. crystallinum (NCBI accession number AF053566) ABA-stress ripening protein. In Salicornia the ASR1 transcript was observed even without the $\mathrm{NaCl}$ treatment, reaching a maximum level at $250 \mathrm{mM} \mathrm{NaCl}$. Time course analysis with $250 \mathrm{mM} \mathrm{NaCl}$ reveals that ASR1 transcript peaks at $12 \mathrm{~h}$ (Fig. 2a, b). The tomato ASR1 gene was expressed transiently in both roots and shoots, reaching a maximum 12-24 $\mathrm{h}$ after the application of salt and dehydration stress (Amitai-Zeigerson et al., 1995). In salt tolerant rice variety Pokkali the transcript was reported even under control conditions, and showed an increase at $6 \mathrm{~h}$ on $1 \% \mathrm{NaCl}$ treatment and thereafter decreased (Vaidyanathan et al., 1999). Similarly, in the present study significant ASR1 transcript was observed under control conditions, indicating that in salt tolerant plants, the ASR1 transcript remains higher in unstressed conditions also.

At high salinity plants maintain ion homeostasis to sustain themselves. Plants maintain a low concentration of $\mathrm{Na}^{+}$in the cytosol by the active exclusion of sodium ions into the apoplast and vacuole by using specific plasma membrane and tonoplast $\mathrm{Na}^{+} / \mathrm{H}^{+}$antiporters. The driving force for this secondary active transport is provided by the PM- $\mathrm{H}^{+}$ATPase and tonoplast $\mathrm{H}^{+}$ATPase (Palmgren, 1998; Ratajczak, 2000). It has been reported that salt treatment of plants induces the activities of the plasma membrane and tonoplast proton pumps (Reuveni et al., 1990; Niu et al., 1993; Perez-Prat et al., 1994; Binzel, 1995; Klobus and Janicka-Russak, 2004). Accumulation of both PM-H $H^{+}$ATPase (Niu et al., 1993; Perez-Prat et al., 1994) and $V-H^{+} A T P a s e$ (Narasimhan et al., 1991) mRNAs under NaCl-stress and the positive correlation with salt tolerance (Braun et al., 1986; Niu et al., 1993; Perez-Prat et al., 1994) are well studied. In the halophyte Atriplex nummularia Lindl., the proton transport capacity of the PM- $H^{+}$ATPase has been reported by higher $\mathrm{Na}^{+}$ concentration (Niu et al., 1993). The $\mathrm{Na}^{+}$stimulation of hydrogen pumping in Atriplex is attributed to increased

Table 4. Regulation of unknown genes by salt stress

\begin{tabular}{|c|c|c|c|c|c|c|c|}
\hline \multicolumn{4}{|c|}{ Down regulated genes } & \multicolumn{4}{|c|}{ Up regulated genes } \\
\hline S. No. & Clone No. & Clone I.D. & Accession No. & S. No. & Clone No. & Clone I.D. & Accession No. \\
\hline 1 & 2 & Sal-A-77.e1 & EB484581 & 1 & 6 & Sal-B-56.e1 & EB484633 \\
\hline 2 & 47 & Sal-F-59.e1 & EB484909 & 2 & 7 & Sal-B-70.e1 & EB484642 \\
\hline 3 & 48 & Sal-G-58.e1 & EB484979 & 3 & 10 & Sal-C-55.e1 & EC906166 \\
\hline 4 & 51 & Sal-H-51.e1 & EB485044 & 4 & 13 & Sal-C-92.e1 & EB484735 \\
\hline 5 & 52 & Sal-A-15.e1 & EB484530 & 5 & 17 & Sal-F-52.e1 & EB484904 \\
\hline 6 & 53 & Sal-A-27.e1 & EB484539 & 6 & 20 & Sal-H-63.e1 & EB485056 \\
\hline 7 & 55 & Sal-A-50.e1 & EB484556 & 7 & 24 & Sal-I-42.e1 & EB485109 \\
\hline 8 & 56 & Sal-A-53.e1 & EB484559 & 8 & 25 & Sal-I-57.e1 & EB485119 \\
\hline 9 & 69 & - & - & 9 & 34 & Sal-H-56.e1 & EB485049 \\
\hline \multirow[t]{12}{*}{10} & 80 & Sal-F-61.e1 & EC906219 & 10 & 35 & Sal-H-72.e1 & EB485063 \\
\hline & & & & 11 & 41 & Sal-H-50.e1 & EB485043 \\
\hline & & & & 12 & 42 & Sal-H-60.e1 & EC906251 \\
\hline & & & & 13 & 59 & Sal-C-16.e1 & EB484673 \\
\hline & & & & 14 & 60 & Sal-C-18.e1 & EB484674 \\
\hline & & & & 15 & 68 & Sal-F-30.e1 & EB484885 \\
\hline & & & & 16 & 70 & Sal-A-48.e1 & EB484555 \\
\hline & & & & 17 & 72 & Sal-C-53.e1 & EB484704 \\
\hline & & & & 18 & 73 & Sal-D-67.e1 & EB484783 \\
\hline & & & & 19 & 74 & - & - \\
\hline & & & & 20 & 84 & - & - \\
\hline & & & & 21 & 88 & Sal-H-43.e1 & EB485036 \\
\hline
\end{tabular}



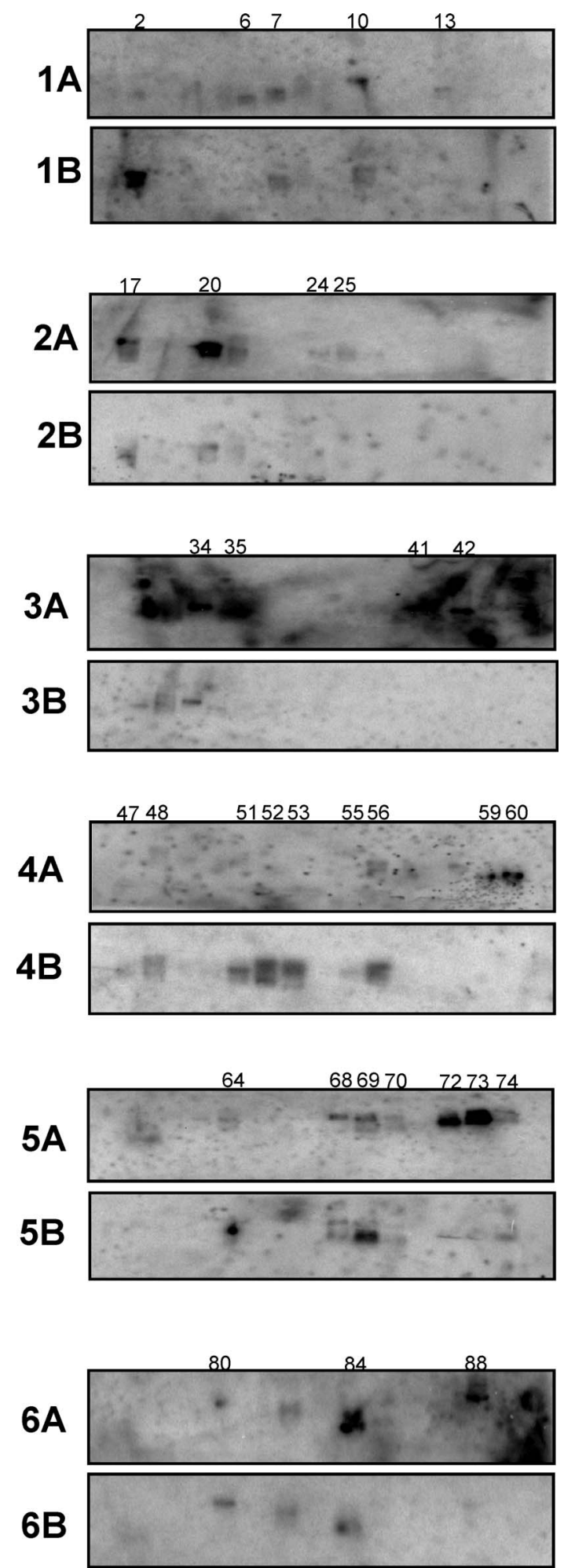

Fig. 4. Figure shows the reverse Northern analysis of the 90 hypothetical/unknown genes. The upper panel (A) is hybridized with salt treated plant's cDNA and lower panel (B) with control plant's cDNA. Clone numbers up or down regulated are mentioned on the top panel.
$P M-H^{+}$ATPase mRNA leading to higher protein level (Braun et al., 1986). In Salicornia the PM- $H^{+}$ATPase transcript was found under control conditions, showing maximum expression at $500 \mathrm{mM} \mathrm{NaCl}$. The highest expression was observed at $8 \mathrm{~h}(250 \mathrm{mM} \mathrm{NaCl})$ treatment (Fig. 3a, b). In $S$. bigelovii the higher $P M-H^{+} A T P a s e$ enzyme activity was reported in $200 \mathrm{mM} \mathrm{NaCl}$ (Ayala et al., 1996). Whereas, in salt cress $T$. halophila no changes in the $P M-H^{+} A T P a s e$ mRNA expression level was observed under salt stress (Vera-Estrella et al., 2005). The time-course analysis of these genes validate that salt tolerance phenomena in Salicornia involve sequential events starting from the constitutive expression of salt responsive genes, the primary induction of key genes followed by expression of other genes.

Reverse Northern analysis We have studied to identify the novelty of the unknown and hypothetical genes by reverse Northern analysis. 90 unknown and hypothetical clones were selected to validate their function in stress tolerance. 21 clones showed up regulation in salt stress, whereas 10 clones showed down regulation (Table 4, Fig. 4). Reverse Northern analysis of a few selected unknown genes from halophyte, smooth cordgrass (Spartina alterniflora Loisel.) revealed much higher abundance of transcripts in response to salt stress (Baisakh et al., 2008). Further analysis of these unknown/unique genes may provide additional stressassociated gene resources from Salicornia.

\section{CONCLUSION}

It is important to isolate ESTs and study known salt responsive genes and unknown genes from halophytes as they have evolved unique mechanisms or regulatory pathways that are not found in glycophytes. Few salt stress related genes like $P M-H^{+} A T P a s e$, Abscisic Acid and Stress Ripening Protein (ASR) have shown the alleviated level of expression even in control conditions, reflecting that in halophytes the salt induced genes are significantly expressed even at control conditions to maintain its normal growth and metabolism. It may be plausible that Salicornia recruits most of the known salt responsive genes for its survival in saline condition but some of the unique genes might also play crucial role in defying the high salt concentration. Further comprehensive profiling of unknown/hypothetical gene from the EST data base showed that many unknown genes also have function in salt tolerance mechanism in this extreme halophyte. Most of the stress related genes identified in the present study are consistent with previously published research in other species. In the long term, the most interesting contribution of this work may be the 'unknown genes' that have been identified, but of course it requires significant further experimentation. 
The authors are thankful to DBT, New Delhi and CSIR, New Delhi (NWP 20) for financial assistance and support.

\section{REFERENCES}

Altschul, S. F., Madden, T. L., Schaffer, A. A., Zhang, J., Zhang, Z., Miller, W., and Lipman, D. J. (1997) Gapped BLAST and PSI-BLAST: a new generation of protein database search programs. Nucleic Acids Res. 25, 3389-3402.

Amitai-Zeigerson, H., Scolnik, P. A., and Bar-Zvi, D. (1995) Tomato Asr1 mRNA and protein are transiently expressed following salt stress, osmotic stress and treatment with abscisic acid. Plant Sci. 110, 205-213.

Amtmann, A., Bohnert, H. J., and Bressan, R. A. (2005) Abiotic stress and plant genome evolution. Search for new models. Plant Physiol. 138, 127-130.

Ayala, F., O'Leary, J., and Schumaker, S. (1996) Increased vacuolar and plasma membrane $\mathrm{H}^{+}$-ATPase activities in Salicornia Bigelovii Torr. in response to NaCl. J. Exp. Bot. 47, 25-32.

Baisakh, N., Subudhi, P. K., and Varadwaj, P. (2008) Primary responses to salt stress in a halophyte, smooth cordgrass (Spartina alterniflora Loisel.). Funct. Int. Gen. 8, 287-300.

Binzel, M. L. (1995) NaCl induced accumulation of tonoplast and plasma membrane $\mathrm{H}^{+}$-ATPase message in tomato. Physiol. Plant. 94, 722-728.

Bray, E. A., Bailey-Serres, J., and Weretilnyk, E. (2000) Responses to abiotic stresses. In: Biochemistry and molecular biology of plants. (eds.: W. Gruissem, B. Buchannan and R. Jones), pp. 1158-1249. American Society of Plant Physiologist, Rockville, Maryland.

Braun, Y., Hassidini, N., Lerner, H., and Reinhold, L. (1986) Studies on $\mathrm{H}^{+}$translocating ATPases in plants of varying resistance to salinity. Plant Physiol. 81, 1050-1056.

Carrari, F., Fernie, A. R., and Iusem, N. D. (2004) Heard it through the grapevine? ABA and sugar cross talk: the ASR story. Trends Plant Sci. 9, 57-59.

Ewing, B., and Green, P. (1998) Basecalling of automated sequencer traces using phred. II. Error probabilities. Genome Res. 8, 186-194.

Ghosh, P. K., Reddy, M. P., Pandya, J. B., Patolia, J. S. et al. (2005) Preparation of nutrient rich salt of plant origin. US patent 6,929,809 B2, 16 Aug 2005.

Issakidis-Bourguet, E., Mouaheb, N., Meyer, Y., and MiginiacMaslow, M. (2001) Heterologous complementation of yeast reveals a new putative function for chloroplast $m$-type thioredoxin. Plant J. 25, 127-135.

Iusem, N. D., Bartholonew, D. M., Hitz, W. D., and Scolnik, P. A. (1993). Tomato (Lycopersicon esculentum) transcript induced by water deficit and ripening. Plant Physiol. 102, 1353-1354.

Kalifa, Y., Pearlson, E., Gilad, A., Konrad, Z., Scolnik, P. A., and Bar-Zvi, D. (2004) Overexpression of the water and salt stress-regulated Asr 1 gene confers an increased salt tolerance. Plant Cell Environ. 27, 1459-1468.

Kiyosue, T., Yamaguchi-Shinozaki, K., and Shinozaki, K. (1994) ERD15, a cDNA for a dehydration-induced gene from Arabidopsis thaliana. Plant Physiol. 106, 1707.

Kłobus, G., and Janicka-Russak, M. (2004) Modulation by cytosolic components of proton pump activities in plasma membrane and tonoplast from Cucumis sativus L. roots during salt stress. Physiol. Plant. 121, 84-92.

Kore-eda, S., Cushman, M. A., Akselrod, I., Bufford, D., Fredrickson, M., Clark, E., and Cushman, J. C. (2004) Tran- script profiling of salinity stress responses by large-scale expressed sequence tag analysis in Mesembryanthum crystallinum. Gene 341, 83-92.

Maskin, L., Gubesblat, G. E., Moreno, J. E., Carrari, F. O., Frankel, N., Sambade, A., Rossi, M., and Iusem, N. D. (2001) Differential expression of the members of the Asr gene family in tomato ( Lycopersicon esculentum). Plant Sci. 161, 739-746.

Mehta, P. A., Sivaprakash, K., Parani, M., Venkataraman, G., and Parida, A. K. (2005) Generation and analysis of expressed sequence tags from the salt tolerant mangrove species Avicennia marina (Forsk) Vierh. Theor. Appl. Genet. 110, 416-424.

Mishra, R. N., Ramesha, A., Kaul, T., Nair, S., Sopory, S. K., and Reddy, M. K. (2005) A modified cDNA subtraction to identify differentially expressed genes from plants with universal application to other eukaryotes. Anal. Biochem. 345, 149-157.

Mittler, R. (2002) Oxidative stress, antioxidants and stress tolerance. Trends Plant Sci. 7, 405-410.

Moran, J. F., Becana, M., Iturbe-Ormaetxe, I., Frechilla, S., Klucas, R. V., and Aparicio-Tejo, P. (1994) Drought induces oxidative stress in pea plants. Planta 194, 346-352.

Munns, R., Cramer, G. R., and Ball, M. C. (1999). Interactions between rising $\mathrm{CO}_{2}$, soil salinity, and plant growth. In: Carbon Dioxide and Environmental Stress. (eds.: Y. Luo and H. A. Mooney), pp. 139-167. Academic Press, San Diego.

Narasimhan, M. L., Binzel, M. L., Perez-Prat, E., Chen, Z., Nelson, D. E., Singh, N. K., Bressan, R. A., and Hasegawa, P. M. (1991) NaCl regulation of tonoplast ATPase $70-\mathrm{kDa}$ subunit mRNA in tobacco cells. Plant Physiol. 97, 562568.

Niu, X., Narasimhan, L., Salzman, A., Bressan, A., and Hasegawa, P. M. (1993) $\mathrm{NaCl}$ regulation of plasma membrane $\mathrm{H}^{+}$-ATPase gene expression in a glycophyte and halophyte. Plant Physiol. 103, 713-728.

Palmgren, M. G. (1998) Proton gradients and plant growth: role of the plasma membrane $\mathrm{H}^{+}$-ATPase. Adv. Bot. Res. 28, 270.

Perez-Prat, E., Narasimhan, M. L., Niu, X., Botella, M. A., Bressan, R. A., Valpuesta, V., Hasegawa, P. M., and Binzel, M. L. (1994) Growth cycle stage dependent $\mathrm{NaCl}$ induction of plasma membrane $\mathrm{H}^{+}$-ATPase mRNA accumulation in deadapted tobacco cells. Plant Cell Environ. 17, 327-333.

Price, A. M., Atherton, N. M., and Hendry, G. A. F. (1989) Plants under drought-stress generate activated oxygen. Free Radical Res. Comm. 8, 61-66.

Ratajczak, R. (2000) Structure, function and regulation of the plant vacuolar $\mathrm{H}^{+}$-translocating ATPase. Biochim. Biophys. Acta 1465, 17-36.

Reddy, M. K., Nair, S., and Tewari, K. K. (1998) Cloning, expression and characterization of a gene which encodes a topoisomerase I with positive supercoiling activity in pea. Plant Mol. Biol. 37, 773-784.

Reddy, M. P., Sanish, S., and Iyengar, E. R. R. (1993) Compartmentation of ions and organic compounds in Salicornia brachita Roxb. Biol. Plant. 35, 547-553.

Reuveni, M., Bennet, A. B., Bressan, R. A., and Hasegawa, P. M. (1990) Enhanced $\mathrm{H}^{+}$transport capacity and ATP hydrolysis activity of the tonoplast $\mathrm{H}^{+}$-ATPase after $\mathrm{NaCl}$ adaptation. Plant Physiol. 94, 524-530.

Riechmann, J. L., Heard, J., Martin, G., Reuber, L., Jiang, C., Keddie, J., Adam, L., Pineda, O., Ratcliffe, O. J., and Samaha, R. R. (2000) Arabidopsis transcription factors: 
genome-wide comparative analysis among eukaryotes. Science 290, 2105-2110.

Shi, W. M., Muramoto, Y., Ueda, A., and Takabe, T. (2001) Cloning of peroxisomal ascorbate peroxidase gene from barley and enhanced thermotolerance by overexpressing in Arabidopsis thaliana. Gene 273, 23-27.

Shigeoka, S., Ishikawa, T., Tamoi, M., Miyagawa, Y., Takeda, T., Yabuta, Y., and Yoshimura, K. (2002) Regulation and function of ascorbate peroxidase isoenzymes. J. Exp. Bot. 53, 1305-1319.

Szabolcs, I. (1994) Soils and salinization. In: Handbook of plant and crop stress. (ed.: M. Pessarakli), pp. 3-11. Marcel Dekker, New York.

Teixeira, F. K., Menezes-Benavente, L., Galvao, V. C., Margis, R., and Margis-Pinheiro, M. (2006) Rice ascorbate peroxidase gene family encodes functionally diverse isoforms localized in different subcellular compartments. Planta 224, 300-314.

Vaidyanathan, R., Kuruvilla, S., and Thomas, G. (1999) Characterization and expression pattern of an abscisic acid and osmotic stress responsive gene from rice. Plant Sci. 140, 21-30.

Vera-Estrella, R., Barkla, B. J., García-Ramiírez, L., and Pantoja, O. (2005) Salt Stress in Thellungiella halophila activates $\mathrm{Na}^{+}$transport mechanisms required for salinity tolerance. Plant Physiol. 139, 1507-1517.

Vinocur, B., and Altman, A. (2005) Recent advances in engineering plant tolerance to abiotic stress: achievements and limitations. Curr. Opinion Biotechnol. 16, 1-10.

Wang, Y. C., Yang, C. P., Liu, G. F., Jiang, J., and Wu, J. H. (2006) Generation and analysis of expressed sequence tags from a cDNA library of Tamarix androssowii. Plant Sci. 170, 28-36.

Wang, Z. I., Li, P. H., Fredricksen, M., Gong, Z. Z., Kim, C. S., Zhang, C., Bohnert, H. J., Zhu, J. K., Bressan, R. A.,
Hasegawa, P. M., Zhao, Y. X., and Zhang, H. (2004) Expressed sequence tags from Thellungiella halophila, a new model to study plant salt- tolerance. Plant Sci. $\mathbf{1 6 6}$, 609-616.

Wang, C.-Q., Xu, C., Wei, J.-G., Wang, H.-B., Wang, S.-H. (2008) Enhanced tonoplast $\mathrm{H}^{+}$-ATPase activity and superoxide dismutase activity in the halophyte Suaeda salsa containing high level of betacyanin. J. Plant Growth Regul. 27, 58-67.

Wong, C. E., Li, Y., Whitty, B. R., Díaz-Camino, C., Akhter, S. R., Brandle, J. E., Golding, G. B., Weretilnyk, E. A., Moffatt, B. A., and Griffith, M. (2005) Expressed sequence tags from the Yukon ecotype of Thellungiella reveal that gene expression in response to cold, drought and salinity shows little overlap. Plant Mol. Biol. 58, 561-574.

Xu, S. M., Wang, X. C., and Chen, J. (2007) Zinc finger protein 1 (THZF1) from salt cress (Thellungiella halophila) is a Cys2/His-2-type transcription factor involved in drought and salt stress. Plant Cell Rep. 26, 497-506.

Yang, C.-Y., Chen, Y.-C., Juah, G. Y., and Wang, C.-S. (2005) A lily ASR protein involves abscisic acid signaling and congers drought and salt resistance in Arabidopsis. Plant Physiol. 139, 836-846.

Zhang, L., Ma, X. L., Zhang, Q., Ma, C. L., Wang, P. P., Sun, Y. F., Zhao, Y. X., and Zhang, H. (2001) Expressed sequence tags from a NaCl-treated Suaeda salsa cDNA library. Gene 267, 193-200.

Zhang, Y., Lai, J., Sun, S., Li, Y., Liu, Y., Liang, L., Chen, M., and Xie, Q. (2008) Comparison analysis of transcripts from the halophyte Thellungiella halophila. J. Integr. Plant Biol. 50, 1327-1335.

Zouari, N., Ben Saad, R., Legavre, T., Azaza, J., Sabau, X., Jaoua, M., Masmoudi, K., and Hassairi, A. (2007) Identification and sequencing of ESTs from the halophyte grass Aeluropus littoralis. Gene 404, 61-69. 